\title{
The Specialized Teacher in a Challenging Task of Teaching: The Case of Two Specialized Teachers in Tunisia
}

\author{
Hanene Lengliz ${ }^{1}$, Neila Ghannouchi ${ }^{2}$, Meher Guerchi $^{3}$, Ali Elloumi ${ }^{4}$, Marie France Carnus ${ }^{5}$ \\ ${ }^{1}$ UMR-EFFETS Laboratory, University of Jendouba, Jendouba, Tunisia \\ ${ }^{2}$ Clinical Psychology, Intersubjectivity and Culture Laboratory, University of Jendouba, Jendouba, Tunisia \\ ${ }^{3}$ UMR-EFETS Laboratory, University of Gafsa, Gafsa, Tunisia \\ ${ }^{4}$ TEC Laboratory, University Paris Descartes, Paris, France \\ ${ }^{5}$ UMR-EFETS Laboratory, University of Jean Jaurès, Toulouse, France \\ Email: hanenelengliz@yahoo.fr
}

How to cite this paper: Lengliz, $\mathrm{H}$. Ghannouchi, N., Guerchi, M., Elloumi, A., \& Carnus, M. F. (2019). The Specialized Teacher in a Challenging Task of Teaching: The Case of Two Specialized Teachers in Tunisia. Advances in Physical Education, 9, 240-257.

https://doi.org/10.4236/ape.2019.94017

Received: July 26, 2019

Accepted: October 25, 2019

Published: October 28, 2019

Copyright (C) 2019 by author(s) and Scientific Research Publishing Inc. This work is licensed under the Creative Commons Attribution International License (CC BY 4.0).

http://creativecommons.org/licenses/by/4.0/

\section{(c) (i) Open Access}

\begin{abstract}
Aim: The main purpose of this study is to explore, analyze and understand the teaching practice of specialized Physical Education (PE) teachers faced to the contingent moment of the class when exercising in the Adapted Physical Activities (APA) which are convened as responses to the basic needs of populations with mental disabilities. Methods: We opted for a cooperative didactic engineering conception linked to a temporal clinical didactic methodology (already-there, test, after-work). Our data collection tools are mainly interviews (ante, post-session, after-work interview), as well as audio and video recording of six gymnastics sessions for each specialized teacher. We relied on a qualitative analysis of data stemming from interviews' verbatim (the sayings) and from the filming of the teaching "test" (the doings). Results: Our results will be presented as two "didactic vignettes" case studies (Ramzi and Mohamed). The content analysis shows that personal and intern determinants related to the teachers' history in terms of sports expertise and professional experience depend heavily on their decisional process when they are encountered with the contingency of the teaching "test". The case study allowed us to prove the singularity of each teacher in his way to conduct and transmit the knowledge stemming from different sources and his own teaching logic that makes him different from the other. Conclusion: The singularity proved in this study reinforces the idea that the most intimate and personal determinants that act out of the control of the teachers affect their link or their relationship to the contingency and the unpredictability of the didactic situation.
\end{abstract}




\section{Keywords}

Clinical Didactic Analysis, Cooperative Didactic Engineering, Case Studies, Specialized Physical Education Teachers, Mental Disabilities,

Temporal Clinical Didactic Methodology, The Specialized Teaching "Test"

\section{Introduction}

Our interest in specialized teaching practice comes from the evolution took place in recent years in the field of adapted physical activities (APA), which are convened as responses to the basic needs of populations with mental disabilities and which enable people with special needs to benefit from "an educational and integrative institutional project enabling them to be consumers of sports practices, a status that until recent years was denied to them" (Biu-Xuan \& Marcellini, 1995). Indeed, in this evolving context, the interest in adapted physical activities and their use in an educational and integrative project highlight:

- On the one hand, the crucial and major importance of thinking about the teaching contents in order to adapt them to the needs and characteristics of people with disabilities.

- On the other hand, the importance of the work of the specialized teacher, who is qualified as a professional subject with a personal journey and a singular relationship to disability. This position allows him to be attentive (or not) to the control and the transmission of adapted knowledge.

In the filiation of the EDIC ${ }^{1}$ works (Terrisse \& Carnus, 2009; Carnus \& Terrisse, 2013), our scientific positioning-which is at the crossroads of the APA didactics and a psycho-analytical clinical orientation-allows us to have other angles of analysis and understanding of the specialized teaching, which is still a developing field in Tunisia. We have chosen to make an entry by the teacher who is considered as a person both in his or her psychic and social dynamics (Beillerot, Blanchard-Laville, \& Mosconi, 1996; Terrisse \& Carnus 2009). This clinical orientation puts forward the teacher's point of view in the analysis and clarification of the didactic functioning (Carnus, 2009). However, the teacher is placed at the heart of three distinct and interdependent instances: the knowledge, the challenge of transmission-appropriation in the teaching and learning process; the specialized institution in which the knowledge is transposed in a non-linear way and under various influences and the "test", which is the moment of truth for decisions, where the "subject" maintains a game of private and intimate relationships with the knowledge (Carnus, 2009).

Therefore, Carnus declares that postulating the teacher's uniqueness and positioning him or her in the center of didactic analyses leads us to call into question a didactic theory that considers the teacher as a person and offers congruent conceptual and methodological options. Three presuppositions found and sup${ }^{1}$ EDIC: clinical didactic team of Toulouse. 
port the choice of "subject theory" (Carnus, 2011: p. 5):

- The teacher as a person is unique, autonomous and responsible. Nonetheless, beyond institutional and contextual restraints, the teachers create their own space of freedom and develop in it. Carnus declares that "such freedom space is partly determined by their decision-making abilities, resulting from a genuine construction of knowledge about what they will teach and how they will teach it. Thus, their personal history, private and professional epistemology, is central to teachers' decisions" (Carnus, 2011: p. 6).

- The teacher as a person is subjugated. In fact, following certain research carried out in mathematical didactics, we notice that the multifaceted institutional subjugations providing a set of co-established rules that are both resources and restraints to the teacher.

- The teacher as a person is divided. "Firstly, the teacher is divided between a private and a public sphere consisting of personal and professional epistemology (what he or she is and is supposed to be, and what he or she knows and is supposed to know). Secondly, the teacher is divided between desires and sensible motivations (restraint or pleasure, following one's plan or controlling one's class). Thirdly, the teacher is divided between consciousness and unconsciousness (what he or she says, what he or she does, what he or she has to do and what he or she cannot refrain from doing)" (op cit, p. 6).

In summary, choosing a clinical orientation and integrating the subjective dimension and the "subject theory" into our work will allow us to have other angles of analysis of teaching practices in a relationship system that goes beyond the didactic relationship between teacher, student and knowledge.

However, we will present in this work two case studies of two specialized teachers who practice in two specialized institutions in Tunisia. We are particularly interested in discovering the effect of their relationship to the specialized teaching "test", their conceptions and representations of disability as well as their experience in this field on their didactic and pedagogical choices. We take into account the fact that the contingency inherent in any didactic situation rises our initial questioning because of the singular way in which a teacher "confronts his desire to transmit in the teaching test" (Brossais, Jourdan, \& Savournin, 2013).

\section{Conceptual Framework}

This article is part of a double theoretical and epistemological filiation: a didactical filiation and a psychoanalytic clinical orientation, with a particular focus on the singularity of the teacher-subject, while in a teaching interaction. In fact, this has to do with accounting for the process by which a teacher transmits (or not) the knowledge that students must acquire. As we take into account the dual determination of a didactic fact produced both by "external constraints" related to the didactic system (Amade-Escot \& Marsenach, 1995) and by "internal constraints" specific to a teacher in particular (Blanchard-Laville, 1996). The teacher-subject is observed in a singular way, considering his personal factors, his 
knowledge, his experience, his intentions, his strategic and didactic choices while considering his desire to teach. However, our choice of an entry with the teacher-subject "taken in the didactic" stems from:

- The fact that the teacher is at the same time the author and the actor of his decisions in the didactical action and that he is "alone, able to say something about the part he takes in what happens to him and to draw the relevant implications" (Terrisse, 2000).

- And from a finding of the inadequacy of didactics available to read some phenomena related to the knowledge transmission-appropriation in physical Education (PE) and more particularly in the teaching of APA.

However, the teaching "test" is considered as a moment of truth and confrontation with the enigmatic reality, where what will happen is unknown. This contingency is inherent to any teaching-learning situation. Carnus declares on this level that the test "is the moment when the subject feels and experiences himself" (Carnus, 2013a: p. 30); it is, among other things, a painful, anxiety-provoking and risky experience. Thus, the result of the didactical situation is unpredictable because the decisions taken by the teacher are mostly originating from an unconscious process which marks the singularity of the subject. This brings us to emphasize a rewriting of the didactical triangle proposed by Terrisse (1994) who replaces the knowledge pole by the test, including the impossibility of any transmission. Knowledge acquires a new status and becomes situated in the bonding of the teacher-student-test, which makes it "an all transmissible step" including a part of the irreducible insu. On the very same line of thought, Sauvegrain (2009) states that the transfer of knowledge from the teacher to the student is not as transparent as one would like; a knowledge does not have to be stated or shown for the students to learn. The teacher cannot transmit all the knowledge and the student cannot make his own entirely (Figure 1).

For this purpose, the notion of the "test" (teaching test) reveals the complexity of the teaching profession qualified according to Freud as "impossible" and emphasizes the internal constraints by opening the possibility of regarding the teacher not only as a rational and mere transmitter of knowledge, but also as "a subject sometimes endowed with a strange logic responding to unconscious motives" (Brossais et al., 2013: p. 94).

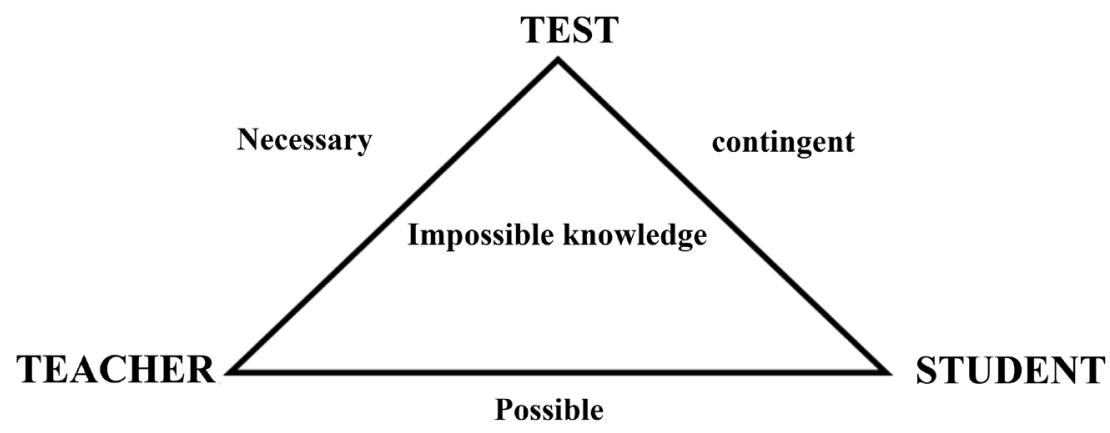

Figure $1^{2}$. Revisited didactic triangle (Terrisse, 1994).

${ }^{2}$ The content of this figure has been translated from its reference source. 
The link to the "test" appears as an essential concept to study the complexity of the specialized teaching activity. We put forward three dimensions of the "link or the relationship to the test" (Jourdan, Brossais, \& Savournin, 2011) that allow us to study this complex activity. We cite the "didactic conversion"; "the subject supposed to know" and the "impossible to bear" (Buznic-Bourgeacq, Terrisse, \& Margnes, 2010). So, these dimensions invite us to outline the notion of relationship to the test.

\section{Analyzers Borrowed from the Psychoanalysis}

\section{1) The didactic conversion "la conversion didactique"}

The "didactic conversion" replaces the term didactic transposition (Buznic-Bourgeacq et al., 2010) in order to refer to the transformation of the experience content into a teaching content. The elements of knowledge constructed by the teacher in his personal experience will organize the content of his effective teaching practices. We talk about experiential transposition from the moment when the teacher transposes his own lived experience into reference knowledge. Blanchard-Laville states that the teacher "is brought to depict his own link to knowledge" and that the latter is "strongly anchored in each person's personal history (...). So, it is not the knowledge that is exposed, it is the subject" (Blanchard-Laville, 2001: p. 109). Thus, the teacher transmits not only knowledge, but also something of his own relation to this type of knowledge. Indeed, the "didactic conversion" helps to organize the content of the teaching practices of a subject in his crossing of the "test" (Brossais et al., 2013: p. 95).

2) The subject supposed to know "le sujetsupposé savoir"

This concept, borrowed by Chevallard (1985) from Lacan, gives the teacher a status that symbolizes him as a subject of knowledge. Thus, as the institutional representative of knowledge, he is immediately assigned to a place from which he is defined. "Its mode of existence refers here to an inscription in a symbolic order which, to precede it, determines it fundamentally" (Buznic-Bourgeacq, Terrisse, \& Margnes, 2010). Thus, the institutional position of the teaching subject in relation to knowledge assigns him or her responsibility for its transmission and places him or her in fact in a supposed symbolic position, that of "supposedly knowing subject".

However, the institutional position of the teacher related to knowledge assigns him or her responsibility for its transmission and places him or her in fact in a symbolic position, that of "supposedly knowing subject". This syntagm developed by Lacan (1966) to characterize the analyst's symbolic position was taken up, on an ad hoc basis, by (Terrisse, 1994; Blanchard-Laville, 2001; Buznic-Bourgeacq, 2009; Buznic-Bourgeacq \& Terrisse, 2013).

\section{3) The impossible to bear "P impossible à supporter"}

This concept, borrowed from the psychoanalysis field, refers to what the teacher, apart from all rationality, cannot refrain from doing. Faced with difficulties that he must manage in urgency and of which he does not have the immediate solution, he has some didactic behaviors which escape any immediate 
rationality, such as sessions interruptions, didactic contract breaks and the delivering of new personal knowledge unrelated to the knowledge taught. To explain them, he takes refuge in justifications with non-didactic basis. The "lack of knowledge" refers to the complex reality of the test, "the real as an impossible to bear", considering the symbolic position of the teacher holder of knowledge. This impossible to bear is "what does not stop being written" (Chémama, 1995) (Table 1).

\section{Material and Methods}

We opted for a cooperative didactic engineering methodology which is defined according to Sensevy \& Mercier (2007: p. 209) as "the production of a new gender which is made under the responsibility of teachers and researchers constructing together common purposes of a process seen as collective". In this study, we have collaborated with the specialized teachers and a hole paramedical team (psychologist, psychomotor therapist and occupational therapist) who work in specialized institutions in Tunisia. The aim of this cooperative participation between the paramedical team and the educational team is to conceive a teaching program to control the "sense of teaching situations" (Artigue, 1990) presented to students with mental handicaps. The co-constructed teaching program is formed of negotiated "didactical script" in regards to command variables ${ }^{5}$ stemming from the "theory of situations" (Brousseau, 1998).

Indeed, our didactical engineering is composed of four consecutive steps (preliminary analyses, engineering conception/a priori analysis, testing and a posteriori analysis) (Sensevy, Forest, Quilio, \& Morales-Ibarra, 2013) interwoven with the clinical didactic methodology characterized with its three research tenses (the already-there, the test and the after-work) (Carnus \& Terrisse, 2013). This methodological corpus has allowed us to create the conditions of an intra and inter site analyses in order to give a detailed account of the pro, inter and retro interactive decisions related to the link that each teacher instigates to handicap, to the APA and to the specialized teaching test. Thus, the imbrication of

Table $1^{3}$. Modeling of the link to the test of teachers (Brossais, 2014: p. 182).

\begin{tabular}{|c|c|c|c|}
\hline \multicolumn{2}{|c|}{ Study object: the teaching "test" } & Analyzers of the "test" & $\begin{array}{c}\text { "Test" composition } \\
\text { modalities }\end{array}$ \\
\hline $\begin{array}{c}\text { Known and } \\
\text { unknown elements }\end{array}$ & $\begin{array}{l}\text { - Sense of the teaching test } \\
\text { - Choices made by the } \\
\text { teacher } \\
\text { - Involvement of the } \\
\text { transmission desire } \\
\text { - Instinctual moves }\end{array}$ & $\begin{array}{l}\text { - Didactic conversion } \\
\text { - The subject supposed to } \\
\text { know } \\
\text { - The impossible to bear } \\
\text { - Link to knowledge }\end{array}$ & $\begin{array}{l}\text { - know-how } \\
\text { - Compromises } \\
\text { - Affects } \\
\text { - Taking action }\end{array}$ \\
\hline
\end{tabular}

${ }^{3}$ The content of this table has been translated from its reference source.

${ }^{4}$ The negotiation of the engineering conception is made over two meetings called "negotiation meetings". They were made about various variables that we judge pertinent in regards to our research problem.

${ }^{5}$ It is about micro and macro didactical variables. The macro didactical variables concern the global organization of the engineering, as for the micro didactical ones concern the local organization of the engineering such as processing variables, motivational variable, etc. 
both didactical and clinical sides provide an original analytical framework to the identification and the analysis of the gaps between intention and decision (Carnus, 2009). The validation of such a methodological device is "in the meeting of a subjectivity identified externally by the researcher, correlated with the descriptions of actual practices, with its internal recognition and its interpretation by the subject himself' (Van Der Maren, 1996). Indeed, several investigation tools were deployed to capture both intern and extern determinants interfering and/or affecting the teaching test.

\subsection{The Observation of the "Test"}

We conducted our test observation by filming six sessions of a gymnastics cycle for each specialized associate teachers. Each session was entirely filmed using two cameras: a mobile camera focused on the teacher who was equipped with a lapel microphone to collect all of his verbal communications; and a fixed camera serving as a control by covering a wide angle of the didactic space. Referring to the techniques of Pourtois \& Desmet (1988) as well as Van Der Maren (1996), we preferred the "immediate" observation which consists of collecting data of different natures: the image and the speech. This complementarity of the "video" and "audio" means is necessary for the analysis of complex and unstable situations. For this purpose, the didactic activities of the associate teachers were described based on audio and video recording of gymnastics sessions (APA support) combined with interview data collected from several types of interviews (preliminary interview of the already-there, ante and post-session interviews and the after-work).

\subsection{The Interviews}

The interviews with the associate teachers have a twofold purpose: to obtain information about their planning projects and conceptions, and to confirm or refute certain data collected during the observation.

\subsubsection{The Ante Session Interview}

The ante session interview allowed us to have a preliminary idea about the initial intentions of the teachers and their goals drawn for the session. The main purpose of this type of interview is to collect specific and precise data on the preparation worksheets, the planned teaching contents and possible changes or modifications related to the experience of the previous session. The purpose of these interviews will, therefore, be to collect a partial and accurate set of information on the forecasts and teaching intentions of each teacher compared to the plans built and negotiated during the course of didactic engineering. Indeed, the questions in the interview guide were formulated in advance and presented in a specific order considering the progress of the interview. The duration of the interview does not exceed 10 minutes.

\subsubsection{The Post-Session Interview}

The post-session interview was conducted straight after the teaching test. Its role 
is to gather information about the immediate effects of the interaction, the decisions made and/or those that the teacher could have made and eventually the future decisions to be modified. It also aims to reveal the discrepancies between what the teacher has planned and what he actually realized. This interview was conducted so as not to influence what the interviewee perceives and feels "off the cuff". From an initial question about the purpose of the session, the initial project or the topic, the interviewer let the teacher speak freely without intervening. It is thus possible to obtain information about the points to which the teacher is sensitive and on those that are problematic to him.

\subsubsection{The After-Work Interviews}

Two after-work interviews took place a few weeks after the filmed observation of the sessions in order to leave a necessary hindsight for the teacher as well as the researcher to identify the evolution of the teacher's personal link to knowledge. Therefore, this interview allows us to explain the difference between the knowledge to teach and the knowledge really and effectively taught, which means the gap between the saying and the doing, the intentions and decisions, so the determination of the process of "reshuffling" that makes sense (Chevallard, 1985). Indeed, the teacher reports afterwards $s^{6}$ on his actions and retrospectively reconsiders his logic of work from a feedback on video recordings, by identifying the significant sequences and more particularly those where the teacher was confronted with difficulties. It is from these video sequences and the verbatim excerpts from after-work interviews that the teacher rethinks, reconstructs and tries to explain and sometimes justifies his didactic actions mostly unconscious.

Indeed, the data processing was made over three chronological: considering the knowledge to teach in the first two steps, then to look for the gaps between the declared knowledge and the knowledge carried out (the already-there and the test $)^{7}$. It is from these discrepancies that we begin to put hypothetical statements that allow us to prepare the after-work. These three steps are assembled in a data triangulation (Huberman, Miles, \& De Backer, 1991) stage which allows us to confront the interpretative statements of the after-work interviews with the a priori analyses. We note that all the verbatim said by both teachers in all kinds of interviews was integrally transcribed in a most faithful way without changing the meanings.

In a nutshell, we propose this figure below (Figure 2) as a summary of our methodological framework for a better understanding of our descriptive and analytical approach.

Our research strategy is based on a didactical framework where we collect data before the sessions including the teaching content to be taught related to the co-constructed script, then data from during the session (test tense) which allows us to analyze the content actually taught with a special focus on the gap between the intentions and the realizations of the teachers and finally data from ${ }^{6}$ After few weeks of the classroom intervention "P après-coup".

${ }^{7}$ This step takes shape methodologically through encodings and templets of condensation of ante and post-session interviews data and through a test analysis grid. 


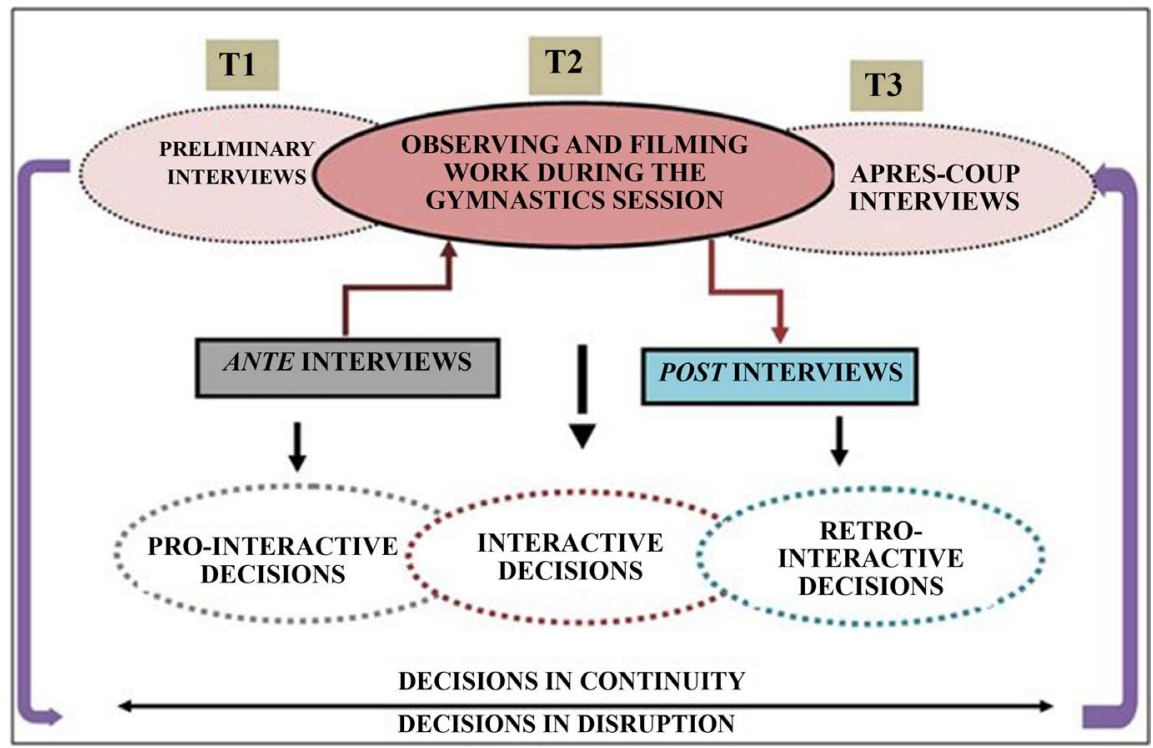

Figure 2. Summary of the methodological framework (Lengliz, 2016).

after the session (after-work tense) to get closer to the teachers' reflections and the personal and singular explications for each one of them.

\subsection{Complementary Reading of the Videos: Analysis Grids}

Furthermore, our methodological corpus allowed us to have audio and video data stemming from interviews and the filming of the sessions taught which permitted us to make back and forth between the "doings" and the "sayings" of both teachers. To that end, we used different steps of content analysis (Van Der Maren, 1996) of the verbatim from ante and post-session interviews and a complementary reading of the videos recorded during the "test" time which targets to nourish our cases analyses. For this purpose, we used analysis grids of the ostensive practices or ostensive forms (Table 2), language approaches (Table 3) and proxemics aspects (Table 4) privileged by our participants during the six sessions taught. These indicators may show their teaching conceptions, their link to the sport activity (gymnastics) as well as their link to the test of specialized teaching. The case study allowed us to highlight the singularity of each teacher including their personal dimension of the specialized teaching.

Several ostensive forms can coexist in teaching practices. Buznic-Bourgeacq (2009) identifies three forms of "ostentation": demonstration, manipulation and explanation through discourse.

- Two forms of demonstration: first we have the total direct physical "ostension" (OPDT) where knowledge is physically demonstrated by the teacher then partial direct physical "ostension" (ODPP) where knowledge is partially demonstrated by the teacher.

- Concerning the second ostensive form-manipulation-there are also two forms: direct and total physical manipulation (ODPP) and partial physical manipulation (OPPP). 
Table 2. grid of ostensive forms (Robert, 2012).

\begin{tabular}{cccccc}
\hline $\begin{array}{c}\text { Events and } \\
\text { footages }\end{array}$ & \multicolumn{2}{c}{ Demonstration } & Manipulation & $\begin{array}{c}\text { Explication through } \\
\text { discourse }\end{array}$ & Non-ostension \\
\hline SESSION N & ODPT & ODPP & OPPT & OPPP & DVO IVO GSO \\
\hline & & Taking in hand & & \\
Setting up & & \\
Main session & Return to calm \\
TOTAL & & \\
\end{tabular}

Table 3. grid of language approaches (according to Carnus, 2011).

\begin{tabular}{lccc}
\hline & $\begin{array}{c}\text { Specific } \\
\text { vocabulary } \\
\text { SV }\end{array}$ & $\begin{array}{c}\text { Usual analogical } \\
\text { register } \\
\text { GR }\end{array}$ & $\begin{array}{c}\text { Metaphoric } \\
\text { analogical register } \\
\text { MR }\end{array}$ \\
Taking in hand & Gymastics session $\mathrm{N}^{\circ}$ & \\
Setting up & \\
Main session & \\
Return to calm & \\
Total &
\end{tabular}

Table 4. Proxemics aspects grid (according to Hall, 1966).

\begin{tabular}{|c|c|c|c|c|c|c|c|c|}
\hline \multirow{2}{*}{$\begin{array}{c}\begin{array}{c}\text { Events and } \\
\text { footages }\end{array} \\
\text { SEANCE N }\end{array}$} & \multicolumn{2}{|c|}{$\begin{array}{l}\text { Intimate distance } \\
\text { (ID) }\end{array}$} & \multicolumn{2}{|c|}{$\begin{array}{l}\text { Personal conversation } \\
\text { distance (PCD) }\end{array}$} & \multicolumn{2}{|c|}{$\begin{array}{l}\text { Interaction social } \\
\text { distance (ISD) }\end{array}$} & \multicolumn{2}{|c|}{$\begin{array}{l}\text { Public distance } \\
\text { (PD) }\end{array}$} \\
\hline & $(\mathrm{CM})^{8}$ & $(\mathrm{RM})^{9}$ & $(\mathrm{CM})$ & $(\mathrm{RM})$ & $(\mathrm{CM})$ & (RM) & $(\mathrm{CM})$ & (ME) \\
\hline \multicolumn{9}{|c|}{ Taking in hand } \\
\hline \multicolumn{9}{|l|}{ Setting up } \\
\hline \multicolumn{9}{|l|}{ Main session } \\
\hline \multicolumn{9}{|l|}{ Return to calm } \\
\hline TOTAL & & & & & & & & \\
\hline
\end{tabular}

- Finally, the third ostensive form is the explanation through discourse which consists of direct verbal ostension (DVO), indirect verbal ostension (IVO) and gestural symbolic ostension (GSO).

This analytical grid of language approaches (verbal register) gives us an idea of the different language registers used by the two associate teachers during their intervention with students with mental disabilities. Thus, we can make a comparison between these two teachers through their pedagogical choices in adapted gymnastics sessions. Indeed, we identified different approaches within the verbal register:

${ }^{8} \mathrm{CM}$ : Close Mode.

${ }^{9} \mathrm{RM}$ : Remote Mode. 
- Either, teachers used a technical vocabulary specific to gymnastics (SV).

- Or, teachers choose to use usual and familiar analogical register (FR).

- Or they adopted Metaphoric and analogical register using different images (MR).

- Or they combined the different language registers.

\section{Results: Didactic Vignettes (Ramzi and Mohamed ${ }^{10}$ )}

We present our findings in the shape of two didactic vignettes: Ramzi and Mohamed, which refer to "short synthetic presentations of the case seen as singular subjects who are observed in a specific environment and temporality" (Carnus, 2013b: p. 25). Indeed, our results are based on the analysis of certain elements of the after-work interviews in which we invited the teachers-subjects to recall certain events happened during the teaching test (excerpts or footages selected by the researcher) in order to clarify and understand the singular professional logic of each one of them impacting their interactive decision-taking and, among other things, to be able to identify the unconscious processes interfering in their teaching practices. Thus, these excerpts illustrate the pertinent interactive decisions to be analyzed in regard to the research questions and to enrich our interpretations.

\subsection{The Case of Ramzi "Practice Makes Perfect"}

Ramzi is a specialist teacher who has been working in the Public Institute Promoting Disability for 9 years. He is specialized in Kickboxing and Taekwondo.

By pursuing Ramzi's "sayings" and "doings", we notice that he holds a contradictory link to handicap. Indeed, we see him sometimes in a position of acceptance and recognition of the handicap and sometimes in a position of denial. In this respect, he admits: "The mentally handicapped person is someone who looks normal apparently, but who may also have a little retardation and an intellectual disability that can be curable with time; you must know that a mentally handicapped person is a limited person, a person who needs guidance and care both intellectually and emotionally"11 (After-work interview). During the preliminary conceptual already-there interview, he told us: "Believe me, disability is in the minds of the people who don't really know the disability" (Indeed, during the teaching test, Ramzi's behavior towards his students is not the same depending on a certain classification. He indulges in classifying his students into as he explains "desperate cases", others "I do not expect anything from them" or " $I$ neglect this kind of student". This way of representing disability, affects Ramzi's choices and teaching strategies. We see him, for example, giving explanations in the form of courses or he transmits knowledge and know-how by a combination of the verbal and the corporal interaction. We also see him excluding some stu-

${ }^{10}$ Ramzi and Mohamed are two pseudonyms assigned to the collaborating teachers in this study in order to preserve their anonymity related to research ethics.

${ }^{11}$ All the italicized texts in this paper refer to verbatim excerpts of different interviews conducted with both teachers. 
dents from the learning scene when he does not see what he expects to see.

Moreover, by analyzing the selected excerpts from Ramzi's after-work interview, we notice his "narcissistic positioning" as a subject supposed to know. Although, he does not point in his speech the important fact of taking into account the characteristics and peculiarities of his students with mental disabilities to intervene. This paradox can be interpreted as a way for this teacher to "always keep his hand" on the transmission of knowledge and to establish his legitimate status as a knowledge holder by showing off his physical competence in gymnastics and his thorough knowledge of the discipline taught. The students concerned in this case must automatically and without fail to follow him in all that he proposes. This becomes even compulsory for the teacher.

This behavior and attitude are declared by Ramzi as a way of doing what he considers the most convenient for this particular kind of students, as he explains: "it's the common language, isn't it! It's true we are there to develop our students on all levels, but I don't work like that, an intellectual disability is not an illness, a student must have the minimum, and I will do the rest" (after-work interview). $\mathrm{He}$ also adds with a serious and convincing tone: "The student must understand very well the principle and the strategy in which I commit myself, otherwise nothing works". He says again: "you see all this, after you find yourself with a student who cannot even raise his arm well taut to make the salute. But what is that? $1 \mathrm{~m}$ very demanding on that, and as long as the student is not quadriplegic, or whatever, he just has a mental retardation so he has to follow me and it's a whole system, a whole strategy" (after-work interview). This very strict and very rigid attitude contradicts sometimes with what he really thinks when he tells us at the end of the after-work interview: "a person with a disability always remains a part of our society, a person who needs follow-up and a lot of coaching. The specialized teacher is one of the people who could have a great influence on the promotion and evolution of this kind of person, that's all'.

Advancing in the analysis of Ramzi's discourse, we note that his primary objective is to show off, as he says, a way of "impressing students". He exposes his body to his students as an image, known from some authors and in the same context with "narcissism", while Freud speaks of a "mirror effect" where the teacher enters into relationship with the other through himself to be able to transmit a knowledge. Narcissistic identification allows self-recognition in the other, a mirror effect of the teaching-self in the other-student (Freud, 1914; Lacan, 1949). Thus, all methods and intervention strategies take Ramzi's ego as a starting point which is quite the opposite of the statement emerged from the negotiation meetings with the whole paramedical team which is: a focus on students with special needs who have particularities and problems on which a teacher must focus to find solutions, makes appropriate didactic choices and thus adapts his teaching to students' needs.

However, this particular approach and attitude lead Ramzi to sometimes show his "impossible to bear" which is at the origin of the mostly unconscious mechanisms influencing his didactic functioning. What is unbearable for this 
teacher comes from the fact that the students' realization does not come up to his expectations, the effort and the energy provided by him. Ramzi chooses, in this case, not to intervene and even to be a little aggressive in regards to his students.

To summarize, we can say that Ramzi seems very attentive to his students' cognitive and motor development. For him, the student in a mental handicap situation must have knowledge on the gesture to be done so that he can remake it by imitation and by repetition. Ramzi is committed to a very authoritative and rigorous didactic approach towards the logic of the gymnastic activity. He is very attentive to the cognitive transmission and focuses on the correction and correctness of the selected elements while ignoring the needs and specificities of the disabled student. "I work this way, I give a lot mentally, I want to get them used to thinking, to control their movement, for me it's very important if it doesn't happen here, (he points once again to his head), they are students in intellectual failure and, well, Ill focus on this failure to develop it, I put my finger on the problem to get rid of it'. Yet, this rigidity and the way of conceiving gymnastics as a very complicated activity and which requires a significant body and cognitive mastery conceals from the eyes of the teacher the evidence of transmitting and teaching by adaptation, taking into account the student who has particular characteristics and who evolves in a particular context. Ramzi opts for a very strict and highly technical didactic logic, he does not set up pedagogical progression situations, the student is supposed to see the element and has to reproduce it as demonstrated and explained by the teacher. The use of the direct physical ostension merged with verbal ostentation ${ }^{12}$. As he spends a long time explaining and using his own body to transmit the information through demonstration. $\mathrm{He}$ clarified more in the after-work interview: "I am obliged to make my body speak". This attitude, shows clearly the teacher's willingness to position himself to his students as a "knowing" subject that focuses, on one hand, on assuming his didactic responsibility for the advancement of knowledge in the classroom through the occupation of the posture of a "subject supposed to know" (Lacan, 1966), on the other hand, to legitimize his pursuit of a narcissist pleasure and a voluntary to establish his "didactic authority".

\subsection{The Case of Mohamed: "My Students Are My Children"; "They Are Everything for Me"; "I Can't Leave Them, It's Stronger than Me"}

Mohamed is a specialized experienced teacher for over 9 years, who is been working in the private center "El Walid". He is a swimming specialist who is in charge of competitive sports activities in the center (swimming, Bucci). Mohamed's didactic approach during the teaching "test" seemed strategic and very thoughtful. Mohamed, despite being aware that he is moving away a little from what has been retained in the engineering, he does not neglect the characteristics

${ }^{12}$ These results stem from a complementary reading of the teaching "test" through a test analysis grid. 
and needs of the students on the one hand and the nature of his intervention in regard to the organizational and communicational plan which will enable him to assume his responsibility as a knowledge-holder teacher on the other hand. Wanting to create a good working atmosphere, have a good class mastery, facilitate students' learning and the teacher's intervention, Mohamed adopts a very routine and risk-free organization. He says: "These children have behavior problems, they are so agitated that I had to put them against the wall so that they can see the demonstration in the first place, see their peers perform successfully and especially ensure a quieter atmosphere, you saw they were a little agitated, I couldn't control the situation otherwise" (after-work interview).

Thus, the essential vector in Mohamed's interactive approach is the search for a balance between the student's needs and the teacher's needs. He says: “I don't see the need to make them work in groups, at least this organization is more beneficial to them and to me from a safety, evaluation and correction point of view. I always do what's best for me and for them too, it's very important'.

In addition, Mohamed presents a very protective pedagogical attitude with his students. His speech shows the very intimate relationship with his students. He goes beyond the adoption of a singular way of doing things, which even becomes a necessity for him and for his students. He also states that it is something that he cannot help not to do. "I can't let them down, it's stronger than me". This reminds us a little of the need for a new born baby to his mother and the relation of affection regarding to them. The teacher needs to see his students succeed (it becomes even necessary for him) and the students need to see their teacher by their side to ensure a certain confidence and a certain sense of security. This caring and very protective attitude are animated by a very specific conceptual already-there of Mohamed who speaks of love towards his students, he says " $I$ love them, my children", he even speaks of adoption saying "we must adopt them, love them, they are everything to me". However, this affective and very personal approach can somehow conceal or even dominate over the content of knowledge and the teaching object which logically remains the goal in any teaching-learning relationship. In Mohamed's speech, there is no focus on what to teach, the most important thing for him is that the students work in a very friendly and family atmosphere. The essential vector in Mohamed's decision-making is the psychological aspect of the pedagogical relationship. The fact of following and accompanying the students since their childhood is a strong argument of this pedagogical orientation change which links the teacher to his student. In fact, Mohamed does not speak about a "students" but rather "children" " $P$ ve forged very strong relationships, it is sure yes, $P$ ve been following them since their childhood, I don't see another reason, it's all so normal, well may be after watching the video that can seem odd but it can't be explained otherwise, my students are my children, I go where they are, I set them in motion, my students".

Indeed, Mohamed insists in his teaching on the student's emotional and personal development. He bases his teaching on a didactical approach where he 
attributes an important place to all its psychological and relational aspects while concealing most of the knowledge mobilized in the negotiated script. Adapted gymnastics remain for him just a means and the mastery of a gymnastic know-how is not an end in itself per se at all. The most important thing, according to him, is to engage the students in unusual gymnastics activities in a conducive climate of trust and pleasure. As for the analytical and technical motor, learning is not considered as a priority at all. His after-work statements illustrate his didactic conception and approach: "the success of the exercise isn't an end, as I said before, my goal is that my students participate and make an effort to the end." He adds: "My students manage to perform gymnastic actions, without taking into consideration the correctness of the gestures, it doesn't interest me, in so much as $P m$ very focused on the fact that my students perform, make a salute, present a sequence, finish their sequence with a smile and a salute, ouuuf that's impeccable in my opinion ... In any case, we can see by far that they do gymnastics and not football, that' $s$ clear" (après-coup interview).

This didactic approach obviously influences the choices and decisions of Mohamed during the intervention. As we can see him, for example, preferring certain ostensive forms that are essentially based on manipulation or total physical ostension, in order to give the students a better chance of succeeding and that they can see what the teacher wants them to see. The overflow of knowledge between Mohamed and his students is characterized by an intensive use of the verbal ostension. The informational volume, the overly generic terms and the familiar and generally approving and positive vocabulary only take into account the effects of the actions and not their causes. The teaching practice of Mohamed relies more on a logic inherent to his lived experience, his knowledge of students and the context, than on that of the activity.

\section{Conclusion}

To conclude, we note a very large difference between these two presented cases, Mohamed and Ramzi. Concerning Mohamed, his starting point and arrival point are the student's emotional development. Ramzi, on the other hand, is primarily interested in gymnastics activity and how to transmit gymnastic knowledge. This attitude legitimizes his status and his symbolic position as a teacher who possesses knowledge.

In this way, Ramzi considers the "test" as a moment when he identifies himself as a knowledge-holder teacher. Ramzi undertakes an approach interpreted as a way of effectively taking over the control of the class and a way of exposing his "self" and, thus, ensuring his symbolic function of a "subject supposed to know". Ramzi favors the global method to teach a gymnastic element. In his decisional logic, Ramzi gives a crucial importance to the students' cognitive development. Thus, he spends a lot of time explaining, demonstrating and making individual technical corrections, which is for him a valuation of his own knowledge. The problems and obstacles which encounter the students must be acceptable to 
Ramzi. As soon as the student's problem devalues the efforts made by the teacher and distorts his image, he opts for rejection and denial to remove everything that seems "impossible to bear". As for Mohamed, the "test" is considered as a material and human organization that allows him to create a psychic interaction space or "psychic play space" (Doron, 1987), where technical error or imperfection is tolerated and acceptable. Since his knowledge of gymnastics is limited (a sport activity that is not taught in the center), it is part of a broader logic of soft skills, which he masters better. He tries to manage the obstacles, the moments of fear and rupture that sometimes mark the activity of his students. The causes of the breaks according to Mohamed are not in the didactic operation mode, but in the moments when the students do not feel confident or when they withdraw from the session. The gymnastic skills and content are not a priority, what is essential is the relational and affective dimension. In fact, faced to the contingency of the "test", Mohamed's material and human arrangement, his use of guided situations in a predictable and arranged environment, then the need for monitoring and closely controlling his students-where the didactical situation is totally managed by the teacher-are revealers of his logic and his conceptual and experiential "already-there" (le déjà-la).

\section{Conflicts of Interest}

The authors declare no conflicts of interest regarding the publication of this paper.

\section{References}

Amade-Escot, C., \& Marsenach, J. (1995). Didactique de l'éducation physique et sportive questions "théoriques et méthodologiques. Grenoble: La pensée sauvage/INRP.

Artigue, M. (1990). Epistemología y didáctica. Recherches en didactique des mathématiques, 10, 3.

Beillerot, J., Blanchard Laville, C., \& Mosconi, N. (1996). Pour une clinique du rapport au savoir. Paris: L'Harmattan.

Biu-Xuan, G., \& Marcellini, A (1995). Redynamisation du sujet: Modélisation générale et usage des activités physiques et sportives avec des publics présentant de graves difficultés d'adaptation. In B. François, \& C. Michel (Eds.), Corps et psychiatrie (pp. 179-190). Psychopédagogie des activités physiques et sportives, Rennes ENSP.

Blanchard-Laville, C. (1996). Aux sources de la capacité de penser et d'apprendre. À propos des conceptions théoriques de WR Bion. Pour une clinique du rapport au savoir, 17-50.

Blanchard-Laville, C. (2001). Les enseignants entre plaisir et souffrance. Presses universitaires de France.

Brossais, E. (2014). Le point de vue du sujet confronté à la transmission de savoirs (Vol. 8). Summary of Paper Presented for Obtaining Accreditation as Research Supervisor. Paris: Université de Paris.

Brossais, E., Jourdan, I., \& Savournin, F. (2013). L'activité enseignante à l'aune du rapport à l'épreuve. In M. F. Carnus, \& A. Terrisse (Eds.), Didactique clinique de l'EPS. Le sujet enseignant en question (pp. 92-103). Paris: Éditions EPS. 
Brousseau, G. (1998). Les obstacles épistémologiques, problèmes et ingénierie didactique.

Buznic-Bourgeacq, P., \& Terrisse, A. (2013). Le sujet en position d'enseignant: pratiques et discours de trois professeurs d'EPS débutants avec ou sans expérience personnelle dans l'activité enseignée. Revue française de pédagogie, 15-28. https://doi.org/10.4000/rfp.4209

Buznic-Bourgeacq, P., Terrisse, A., \& Margnes, E. (2010). La transmission du savoir expérientiel en EPS: Études de cas et analyses comparatives en didactique clinique.

Buznic-Bourgeacq, P. (2009). La transmission du savoir expérientiel. Études de cas et analyse comparative en didactique clinique de l'EPS. Thèse de doctorat en sciences de l'éducation, Université de Toulouse.

Carnus, M. F. (2009). La décision de l'enseignant en didactique clinique. Etude de cas en Education Physique et Sportive. In A. Terrisse, \& M. F. Carnus (dir), Didactique clinique de l'EPS, quels enjeux de savoirs (pp. 63-81). Bruxelles: De Boeck.

Carnus, M. F. (2011). Comparative Linguistic Analysis between Newly Qualified Teachers and Experienced Teachers: A Study of the Notion of Pelvic Retroversion in Physical Education. Physical Education \& Sport Pedagogy, 17, 37-59.

https://doi.org/10.1080/17408989.2010.550143

Carnus, M. F. (2013a). Le sujet enseignant n'est pas maître dans sa propre institution. In M. F. Carnus, \& A. Terrisse (Eds.), Didactique clinique de l'EPS. Le sujet enseignant en question (pp. 23-32).

Carnus, M. F. (2013b). Didactique clinique de l'EPS: Le sujet enseignant en question. Ed. EPS.

Carnus, M. F., \& Terrisse, A. (2013). Didactique clinique de l'EPS, le sujet en question. Paris: Revue EPS.

Chémama, R. (1995). Dictionnaire de la psychanalyse. Paris: Larousse

Chevallard, Y. (1985). La transposition didactique (Vol. 95). Grenoble: La pensée sauvage.

Doron, J. (1987). Introduction à la seconde édition du Moi-peau à l'enveloppe psychique, Les enveloppes psychiques. Paris: Dunod.

Freud, S. (1914). Pour introduire le narcissisme.

Hall, E. T. (1966). The Hidden Dimension (Vol. 609). Garden City, NY: Doubleday.

Huberman, A. M., Miles, M. B., \& De Backer, C. (1991). Analyse des données qualitatives: Recueil de nouvelles méthodes (The Analysis of Qualitative Data: Collecting New Methods) (pp. 88-138). Bruxelles: De Boeck Université.

Jourdan, I., Brossais, E., \& Savournin, F. (2011). Du rapport au savoir au rapport à l'épreuve: le point de vue de deux professeurs stagiaires à l'IUFM. Recherche \& formation, 66, 9-22. https://doi.org/10.4000/rechercheformation.1064

Lacan, J. (1949). Cure psychanalytique a l'poupee fleur. Comptes rendus, reunion, 18.

Lacan, J. (1966). Le stade du miroir. Écrits, 94.

Lengliz, H. (2016). Analyse didactique clinique des pratiques enseignantes spécialisées auprès d'élèves en situation de handicap mental. Etude de cas rapprochés de quatre enseignants spécialisés en Tunisie. Toulouse: Université JEAN JAURES Toulouse.

Pourtois, J. P., \& Desmet, H. (1988). Tendances actuelles de la recherché en éducation familiale. Éducation familiale. Un panorama de recherches internationales, 247-278.

Robert, M. (2012). L'ostension non verbale en EPS: Analyse didactique clinique des pratiques gestuelles de deux enseignants aux profils contrastés lors de l'enseignement de la rotation avant. Mémoire en Master 2 recherche Éducation, Formation, Travail et Savoirs, UTM. 
Sauvegrain, J. P. (2009). Chapitre 9. L'appropriation du savoir par l'élève en cours d'EPS. Une étude de cas en lutte. In Didactique clinique de l'éducation physique et sportive (EPS) (pp. 145-156). De Boeck Supérieur.

Sensevy, G., \& Mercier, A. (2007). Agir ensemble: L'action didactique conjointe du professeur et des élèves. Rennes: Presses universitaires de Rennes.

Sensevy, G., Forest, D., Quilio, S., \& Morales-Ibarra, G. (2013). Cooperative Engineering as a Specific Design-Based Research. The International Journal on Mathematics Education, 45, 1031-1043. https://doi.org/10.1007/s11858-013-0532-4

Terrisse, A. (1994). La question du savoir dans la didactique des APS: essai de formalisation, note de synthèse pour l'Habilitation à Diriger des Recherches. Toulouse: Université Toulouse III.

Terrisse, A. (2000). Epistémologie de la recherche clinique en sports de combat (Clinical Research Epistemology in Combat Sport). Recherches en sports de combat et en arts martiaux, 95-108.

Terrisse, A., \& Carnus, M. F. (2009). Didactique de l'éducation physique et sportive. Quels enjeux de savoir.

Van der Maren, J. M. (1996). Méthodes de recherche pour l'éducation (Research Methods in Education) (Vol. 6). De Boeck Supérieur. 